\title{
CONCEPTUAL EQUIVALENCE AS A CRITERION OF TRANSLATION QUALITY ASSESSMENT
}

\section{Popovych N. M.}

\section{INTRODUCTION}

This study is based on the recent contributions in the fields of translation studies and mostly translation criticism, corpus linguistics with its corpus-based language research and collecting of different statistic data on language use and variety, conceptual semantics that roots mostly on R. Jackendoff's theory of lexical concepts and other relevant to its subjectmatter fields.

J. Naudé provides six assumptions for the translation of religious texts, i.e., (1) translation of religious texts as normal translation, (2) translation of sacred texts as opening up of a foreign culture, (3) translations of sacred texts for specific purposes, (4) utilising translation strategies instead of striving towards equivalence, (5) a descriptive instead of a normative analysis of the translations of sacred texts and (6) cultural knowledge in the translation of sacred texts is shaped by the epistemology, hermeneutics and religious spirituality of the translators ${ }^{1}$. Hence, according to these assumptions the right principles of religious text translation do not still exist and the religious text translatability is very difficult to reach.

Many Ukrainian, Western European and American scholars contributed to the development of the theory of equivalence and translatability.

O. O. Potebnya suggested the preservation of the unity of the external form, content and internal form of the source text in the target language text, V. N. Komissarov developed the hierarchical model of equivalence, A.D. Shveitser suggested the layered model of communicative and pragmatic equivalence, Ya. Y. Retzker in 1974 elaborated the theory of regular correspondences (equivalence within the text units). E. Nida, J. Catford, H. Hönig, M. Snell-Hornby, G. Jäger, use the notion of "equivalence" as a key term for Western European and American translation studies scientific schools. Western European scholars differentiate full equivalence and relative equivalence. Supporters of the first tendency were E. Naida, J. Ketford, G. Hönig, P. Kussmaul, K. Rice,

${ }^{1}$ J. Naudé, Religious translation / J. Naudé // Handbook of Translation Studies,ed. Yves Gambier and Luc van Doorslaer. Amsterdam/Philadelphia: John Benjamins Publishing Company. Vol. 1. 2010. 458 p. P. 285-292. 
G. Fermeer, M. Snell-Hornby. Jäger, V. Koller, J. Albrecht, and G. Gertzimisch-Arbogas supported the second type of equivalence. In 1965, J. Catford suggested formal and text-level equivalence.

E.Nida preferred the term "functional equivalence".What the term "functional equivalence" suggests is not just that the equivalence is between the function of the source text in the source culture and the function of the target text (translation) in the target culture, but that "function" can be thought of as a property of the text. It is possible to associate functional equivalence with how people interact in cultures ${ }^{2}$.

Correspondence of the source language unit to the target language unit on the level of their conceptual sememe component correspondence which are characterized by image, perceptual and value connotations ${ }^{3}$.

Translated and Ukrainian religious concepts and religious terminology were studied in various aspects by G. Baran, S. Bibla, S. Bogdan, O. Biletsky, S. Bilyk, T. Vilchynska, L. Voronovskaya, S. Garbuz, I. Grimalovsky, Ya. Dzoganik, G. Didyk-Meush, U. Doboshevych, E. Zhernovy, V. Zadorozhny, L. Zakrenitska, O. Ivashchenko, Z. Kasprishin, M. Kolbuch, Z. Kunch, G. Kuz, O. Kurganova, I. Lopushinsky, T. Markotenko, O. Matushek, G. Nakonechna, V. Nimchuk, Hilarion (Ohienko), M. Petrovich, N. Poddubna, L. Polyuga, M. Priymich, O. Pryskoka, N. Puryaev, M. V. Skab, K. Simovich, Y. Chernyshova, M. Fabian, L. Fedash, P. Chuchka, I. Shevchenko, M. Shtets, A. Yasinovskyi and O. Yasinovskyi.

Corpus linguistics is relevant to the study of translatability and translation equivalence theories, conceptual equivalence and verbalized concepts in the target language text by means of different corpus-based tools. FrameNet is one which gives the possibility to closer study of the verbalized target language concepts and their componential meanings and "is based on a theory of meaning called Frame Semantics, deriving from the work of Charles J. Fillmore and colleagues (Fillmore 1976, 1977, 1982, 1985, Fillmore and Baker 2001, 2010). The basic idea is straightforward: that the meanings of most words can best be understood on the basis of a semantic frame, a description of a type of event, relation, or entity and the participants in it" ${ }^{\text {. }}$.

\footnotetext{
${ }^{2}$ Nida, Eugene A., Charles R. Taber. (1969). The Theory and Practice of Translation, With Special Reference to Bible Translating, 200. Leiden: Brill. P. 51.

3 Попович Н.M. Давньогрецька тринітарна термінологія у різномовних перекладах (На матеріалі патристичної літератури IV століття): монографія / науковий редактор проф. Клименко Н.Ф. Ужгород: Видавництво УжНУ «Говерла», 2018. 309 с. С. 43-50.

${ }^{4}$ What is FrameNet? [Online]. Available: https://framenet.icsi.berkeley.edu/fndrupal/ WhatIsFrameNet.
} 


\section{Main issues of religious text translatability}

It is known that the problem of translatability has existed since the time the practice of translation existed itself. There were attempts to theoretically substantiate and address the problems of translatability by contemporaries and even precursors of the Fathers of the Church. Such was the experience of the famous translator Saint Jerome of Stridon. In addition to the translation of the Gospel into Latin, i.e., the Vulgate, the writer and translator raised the issues of translatability, recognizing the difficulties of translating "the Chronicles" of Eusebius into Latin.

N. Kholmohorova, the translator of St. Jerome's "Letter LVII. To Pammachius on the Best Method of Translating” into Russian ${ }^{5}$, underlines that the voices of the Church Fathers remained unheard in today's discussions on the principles of biblical translation. Although main translation issues and difficulties discussed by Church Fathers remain very similar and close to nowadays' translation issues in the field of religious translation, they have not been completely resolved yet.

The absence of one text of the Holy Bible in Ancient Greek and Latin recognized by all Christian Churches, different ways of translating biblical texts suggested by the Ancient Greek philologists who had been developing the principles and the rules of translating for centuries, the importance of adequate biblical translations and its adaptability for every unusual doctrine are only a few issues the translators of the 4th century had to face and resolve. To gain the adequate translation of religious text today's translator faces the same difficulties and has to overcome similar obstacles to prove that the notion of translatability is more developed and the principles of translatability are fixed.

J. Naudé tends to divide the developmental history of Bible translation into four Great Ages. " The First Great Age (about 200 BCE to the fourth century CE) has a Jewish setting (Alexandria and Western Asia) and the target languages involved were Greek (Septuagint) and Aramaic (Targums \& Peshitta). The Second Great Age (fourth century CD to about 1500 or the Middle/Dark Ages) was Catholic in origin with its main centers in Palestine and the emerging Christian communities in the Roman Empire. The target language was Latin (Jerome's Vulgate). A salient feature of this age is the Christianising of the Hebrew source text; thus new meaning and nuances were read into Hebrew and Greek-Septuagint words and phrases. The Third Great Age (about 1500-1960) has an essentially Protestant setting.

\footnotetext{
${ }^{5}$ Иероним Стридонский. Письмо LVII. К Паммахию о наилучшем способе перевода / Иероним Стридонский; [пер. с латыни Н. Холмогоровой, под редакцией М. Касьян и Т. Миллер] // Альфа и Омега. № 4(7). 1995. С. 173-187.
} 
The target languages were English, German, French, Dutch, Spanish, etc. The main centers of activity were located in those regions where the (essentially Protestant) trade communities were developing at the expense of the old (essentially Catholic) feudalist establishments. ... The Fourth Great Age/Epoch/Phase in Bible translation introduces a significant change in the overall philosophy of Bible translation. It shows the unprecedented attempt on the part of the Jewish, Catholic, and Protestant communities in the United States and Great Britain to cooperate interconfessionally".

Translatability and translation assessment criteria (TAC) have been raised for discussion by many generations of translators until now. As it was already stated in many scientific contributions to translatability issues, text translating as a process undergoes multilayered transformations until it is recreated in the socio-cultural tradition of the target language. To compare the stylistic and lexico-grammatical features of the text translated into the target language, to assess its quality and see better and more faithful equivalents for specific terminology etc. are the tasks of translator himself or his colleagues, i.e. translation critics.

Multicultural differences, language similarity and dissimilarity, source and target texts time distance, individual and very particular author's picture of the world, verbalized concepts of the source language text are those obstacles, to name just few, translator has to overcome to make the target text adequate, faithful and accessible to the target reader or listener.

The highest possible level of translatability can be defined by E. Nida and C.R.Taber (1974) thesis. They "view translation as reproducing in the receptor language the closest natural equivalent of the source text, first in terms of meaning and secondly in terms of style. A translation is dynamic equivalent to the source text if the message of the source text has been transported into the receptor language in such a way that the response of the receptor is essentially that of the original receptors" ${ }^{\text {" }}$.

\section{The Idea of Corpus-Based Concept Analysis of the Target Religious Texts}

Corpus-based language study increased tremendously during the last two decades. Corpus tools are applied in language acquisition techniques, support indispensably translation or interpreting activities and are of great

${ }^{6}$ J. Naudé, Religious translation / J. Naudé // Handbook of Translation Studies,ed. Yves Gambier and Luc van Doorslaer. Amsterdam/Philadelphia: John Benjamins Publishing Company. Vol. 1. 2010. 458 p. P. 288-289.

${ }^{7}$ 1. Naudé J., Religious translation / J. Naudé // Handbook of Translation Studies,ed. Yves Gambier and Luc van Doorslaer. Amsterdam/Philadelphia: John Benjamins Publishing Company. Vol. 1. 2010. 458 p. P. 289.. 
importance for specific linguistic research purposes. Corpus tools aimed at completing different linguistic tasks can be classified into groups in accordance with the needs of the final user. Some recent classifications of corpus tools and corpus toolboxes has outlined the discrepancy between real functional and desirable multifunctional adaptability of corpus tools in resolving the above mentioned tasks.

The notion "linguistic corpus" means "electronically available collection of texts or transcripts of audio recordings which is sampled to represent certain language, language variety or other linguistic domain" ${ }^{\text {. }}$ Although optionally, text corpora and corpus tools comprise the levels of linguistic analysis called linguistic annotation ${ }^{9}$. The data collected into corpus "can vary tremendously in quality and quantity depending on the research design" "Previously proposed classifications of corpora and corpus tools were aimed at developing the tool which, within the bulk of mainstream corpus tools available nowadays, would be of task-based functionality or multifunctionality and would extract that kind of information from the text data the researcher needs for the ongoing investigation" "10. Hence, it was suggested to classify corpora and corpus tools into groups for better understanding of their advantages and disadvantages and for putting forward the solutions of the underlying problems. We divide corpus tools and corpora into four major groups: (1) content-based, (2) functionality-based, (3) aim- or purpose-based and (4) generation-based corpora and corpus tools. There is also a great number of different linguistic tools, i.e., so-called corpus software tools directed toward the accomplishment of one task either linguistic or statistic in its nature. Among them are offline and web-based concordancers like AntConc (v.3.5.8, February 18, 2019), WordSmith Tools (v. 7, 2019), \#LancsBox (v 4.0, 2018), JConcorder (ver. 1.beta.13, 2011), text coding, (manual) annotation programs, text-analysis tools \& search engines like DART (ver. 3.0, 2019), Dexter and tools \& resources for transcribing, annotating or analyzing texts (inc. speech or audio-visual) like CLaRK, ELAN (EUDICO Linguistic Annotator), GATE (General Architecture for Text Engineering), stats tools like Log-likelihood and effect size calculator, taggers like CLAWS, Stanford POS tagger and others ${ }^{11}$.

${ }^{8}$ S. Kübler and H. Zinsmeister, Corpus Linguistics and Linguistically Annotated Corpora (Engli.sch), New York; London: Bloomsbury Academic, 2015. P. 21-156. http://dx.doi.org/ 10.5040/9781472593573.

${ }^{9}$ Ibid.

${ }^{10}$ A. Lutskiv, N. Popovych. (8-11/10.2019). Adaptable Text Corpus Development for Specific Linguistic Research in Proc. of 2019 IEEE International Scientific and Practical Conference "Problems of Infocommunications. Science and Technology".

${ }^{11}$ Ibid. 
Content-based corpora and corpus tools can be subdivided into 1.1. national, 1.2. professional, 1.3. parallel, 1.4. comparable, 1.5. specialized and 1.6. task-based (adaptable or mixed). The examples of English corpora are vastly overrepresented and described in a number of English corpus reviews, but to be named English national corpora or pretending to be of standard English, there are only a few of them worth mentioning. The Brown Corpus of Standard American English or the Brown Corpus by W.N. Francis and H. Kucera, the British National Corpus managed by the BNC Consortium and the Corpus of Contemporary American English are the most vivid examples of national corpora of both British and American English. Firstly, they all are monolingual, i.e., representing modern British English or American English, but not other languages written or spoken in those countries. Secondly, they are synchronic and general, i.e., including many different styles and varieties, and are not limited to any particular subject field, genre or register and containing examples of both spoken and written language. And finally, both the British National Corpus and the Brown Corpus are sample corpora that allow for a wider coverage of texts within certain limit.

Ukrainian National Corpora are represented by several projects which have been realized till nowadays. Corpus of the Ukrainian Language (N. Dartchuk, O. Siruk, M. Langenbach, Ya. Khodakivska, V. Sorokin at the Institute of Philology of TKU of Kyiv), Laboratory of Ukrainian (Ukrainian) and General Regionally Annotated Corpus of Ukrainian (GRAC) (Ukrainian), to name just a few which are the most developed of the Ukrainian language corpora and corpus tools. The latter are not the same in terms of quality and effectiveness in comparison to those developed for the English language analysis and for English user. English corpora and corpus tools have larger range of choice and are of different content, purpose and functional capacity.

Professional corpora and corpus tools are more content-oriented and focused on specialist language and vocabulary like Air Traffic Control (ATC) Corpus or Carnegie Mellon Communicator Corpus.

OPUS is one of the best examples of parallel multilingual corpora which contains converted and aligned free online data and added linguistic annotation. OPUS project team provides the community with a publicly available parallel corpus. It is based on open source products and the corpus is also delivered as an open content package.

Another type of multilingual corpus is comparable corpus which consists of original texts rather than translations where all texts are similar in content, but they differ in languages or language varieties in the sense that the texts of the same domain are aligned. These types of corpora are 
aimed at comparing the languages or varieties presented in similar circumstances of communication, without the distortions which appear in translated texts of parallel corpora.

To specialized corpora belong BASE (British Academic Spoken English) compiled by Hilary Nesi and Paul Thompson, BAWE (British Academic Written English), LANCAWE (Lancaster Corpus of Academic Written English) to name just a few.

All above named corpus groups can be also classified according to their functional annotation set into linguistic on the word level, syntactic, semantic and discourse. According to their aim or purpose corpora or corpus tools are divided into corpora for linguistic research and statistical data extraction. Language learner's corpus is highly demandable in the L2 acquisition process. Parallel and comparable corpora and other corpus tools are used in translation. The last type among aim-based corpora we identified is for lexicographical language study ${ }^{12}$.

Corpus-based concept analysis as a type of linguistic research is one of the newest trend in the corpus linguistics language analysis. The FrameNet project is one of the most relevant tool which could be used for corpusbased concept analysis. It has been in operation at the International Computer Science Institute in Berkeley since 1997 and presents a lexical database of English that is both human- and machine-readable, based on annotating examples of how words are used in actual texts ${ }^{13}$.

Corpus-based conceptual seme analysis of verbalized religious concepts would facilitate the interrelations on the level of conceptual seme equivalence study. FrameNet project, although it can satisfy more than 13,000 word senses, which are with annotated examples that show the meaning and usage and serve as a valence dictionary, with uniquely detailed evidence for the combinatorial properties of a core set of multilingual vocabulary, it is still cannot provide conceptual seme analysis using parallel corpora as a source and extract the minimal seme meaning of the verbalized concept. This idea found its realization in the mutual interdisciplinary project dedicated to the adaptable corpus development aimed at fulfillment of specific linguistic research. The software tool comprises the quality, effectiveness, option-based functionality and is taskbased or adaptable to specific linguistic research tasks with higher level of big data workflow capacity and less ambiguity indicator. Data analysis process is expected to allow the automation process of finding:

${ }^{12}$ Lutskiv A., Popovych N. (8-11/10.2019). Adaptable Text Corpus Development for Specific Linguistic Research in Proc. of 2019 IEEE International Scientific and Practical Conference "Problems of Infocommunications. Science and Technology".

${ }^{13}$ About FrameNet. [Online]. Available: https://framenet.icsi.berkeley.edu/fndrupal/about. 
1) generate - terms relevant to concepts; 2) synonyms; 3) polysems; 4) terms which are close by their meanings; 5) documents which are close by their meaning; 6 ) the most important terms in the documents.

An initial successful step in this direction has been taken on the example of the Holy Bible English translations with the analysis of more then1140 texts and shown the relations between concepts (such as light, road, life, heaven, temple etc.), documents and terms ${ }^{14}$.

\section{Classification of religious text information and the notion of conceptual equivalence}

\section{(On the Example of the Ancient Greek Religious Concept “Light”)}

The hypothesis of this study is based on the assumption that the information contained in the specialist' texts of the Ukrainian language is divided into three genera: 1 . The first-class information - conceptual, based on a conceptual schema or semantic network of interrelated concepts and concepts of a particular field of knowledge ${ }^{15}$; “ 2 . The second-class information - objectively logical and objective information in the author's vision of the surrounding world; 3. information of the third class subjective information: evaluative, emotional information, i.e., feelings, emotions, mood of the author" 16 .

The percentage of all three types of information in the texts of the seven styles of the Ukrainian literary language is different. Not all types of information are present in the individual style texts. For example, for the most part, scientific and technical texts do not contain the third kind of information, since they are devoid of the emotions, feelings and moods of the author.

On the example of the verbalized Ancient Greek religious concept "light" we are going to demonstrate the dependency of the content of the text on the sense power of the verbalized concept and the specificity of conceptual componential analysis of the verbalized conceptual sememe.

The concept of light is one of the most popular verbal icons of many cultures, religions and national traditions. There was suggested a twofold perspective of the concept development and its inner sense changeability by means of componential concept seme analysis. The continuity of one

${ }^{14}$ Lutskiv A., Popovych N. (8-11/10.2019). Adaptable Text Corpus Development for Specific Linguistic Research in Proc. of 2019 IEEE International Scientific and Practical Conference "Problems of Infocommunications. Science and Technology".

${ }^{15}$ Дэвидсон Д. Об идее концептуальной схемы / Д. Дэвидсон // Аналитическая философия. Избранные тексты [Сост. А.Ф.Грязнов]. - М.: Изд-во МГУ. - 1986 - С. 144-159.

${ }^{16}$ Некряч Т. Є. Через терни до зірок : труднощі перекладу художніх творів. Для студентів перекладацьких факультетів вищих навчальних закладів : навчальний посібник / Т. Є. Некряч, Ю. П. Чала. - Вінниця: Нова Книга, 2010. - 195 с.

96 
and the same verbalization of different and even polar concepts is also held as a fact not needed to be proved. The multilingual text passages rich in verbal representation of concept "light" and descending from different religious traditions and periods were examined for the quantitative results of the research.

M. Arranz, F. E. Brightman, F. J. Dölger, P. H. Engberding, John R. K. Fenwick, F.-N. Klein, V. Vojtovych, Metropolinat Ilarion (Ohiyenko) treated the concept of light from the viewpoints of religions' history and Christian liturgical traditions. Many investigators studied the verbalized concept of light from the linguistic point of view. The interdisciplinary study of such concepts is revealed to be an effective approach that helps to make apparent the continuity of the outer form (verbalized concept) through changeability and variations of the inner form (key ideas of different religions represented by one and the same verbalized concept). Hence, the verbalized concept outer form continuity through changeability of inner senses under the influence of different religious beliefs and traditions proved the fact of conceptual componential analysis necessity for the icons, notions and terms stylistically marked and concept dependent. In particular, the excerpts from ancient Hebraic berakhot, archaic classical and neo-hellenistic anaphoras, original and translated works of st. Basil the Great, prayers and liturgical rite of Eastern Christian tradition of Ukraine proved the fact of continuity through changeability of inner senses under the influence of different religious beliefs and traditions.

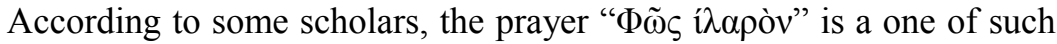
vivid examples of an interrupted verbalized concept existence. It takes its use in Hebraic berakha (thanksgiving to the evening light) through different prayer text forms to a magnificent prayer and chant completed by st. Basil the Great. Preserved in the Ukrainian Christian traditions of the Eastern rite this prayer reveals the live verbalized presence of Hebraic and Christian traditions till nowadays Although st. Basil transformed the key idea of the prayer and the concept of light is present in the prayer text as a simile to compare Light with one God in Trinity, a Hebraic verbalized idea of thanksgiving to the evening light is conserved at the very beginning of the prayer text:

The methodological foundations in the history of the translatability and the factors that determine the translatability dynamism require clarification of important translation concepts such as faithfulness, equivalence and adequacy. The ideas of the faithfulness, equivalence and adequacy in translation is based on the correlation of criteria and requirements that have been put forward by the scientist. The main objective to pursue was to find an approach that would preserve the integrity of the external form 
(lexico-grammatical word form), content (lexical meaning), and internal form (sense or conceptual meaning) of the original in translation"17.

One approach is to trace back the translating traditions which had been created for centuries. It is worth mentioning that in translating verbalized Ancient Greek concepts like " $\varphi \tilde{\omega} \varsigma$ " two translation traditions of the Ancient Greek Patristic texts should be taken into consideration. These two translating traditions made apparent through aspect comparative translation studies analysis. One tradition, so-called "Latin tradition", is the translation from Greek by the mediation of Latin translations. This translation influence is traced in the German, English and Italian translations of the Ancient Greek Patristic texts and concepts.

The second translating tradition, so-called "Slavonic tradition", is the translation from Greek by the mediation of the Ancient Bulgarian language. The second tradition is present in the Russian and Ukrainian translations of the Greek Patristic texts. The dependence on these traditions of the modern translations of the Ancient Greek Patristic texts is easy to trace in Trinitarian terminology translations and verbalized Trinitarian concepts. The source and target texts of the famous Prayer $\Phi \tilde{\omega} \zeta$ i $\lambda \alpha \rho$ òv, which are given below, demonstrate many cases of inadequacy in translating verbalized concept. Word-for-word, sense-to-sense, author's interpretation are the examples of possible concept translation into the target language. Concept "light” has several conceptual semes preserved in the target language texts, i.e., (1) the Divine Light (God's Nature), (2) the ineffable light, and the vision of the holy and sovereign Trinity, (3) onlybegottenly from the unbegotten light, (4) His uncreated light etc.

Table 1

\begin{tabular}{|c|c|c|}
\hline \multicolumn{3}{|r|}{ Original and Translations of the Prayer $\Phi \tilde{\omega} \varsigma$ i $i \lambda \alpha \rho \grave{v} v$} \\
\hline -ن & 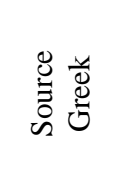 & 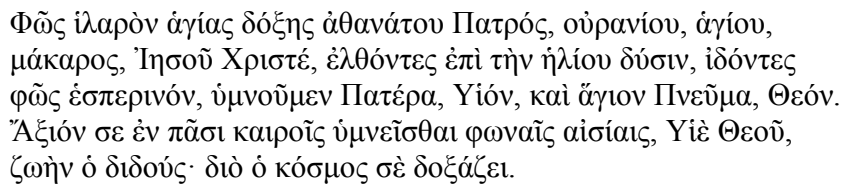 \\
\hline vi & 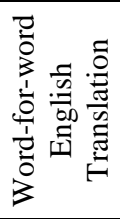 & $\begin{array}{l}\text { O Light gladsome of the holy glory of the Immortal Father, the } \\
\text { Heavenly, the Holy, the Blessed, O Jesus Christ, having come } \\
\text { upon the setting of the sun, having seen the light of the evening, } \\
\text { we praise the Father, the Son, and the Holy Spirit: God. Worthy it } \\
\text { is at all times to praise Thee in joyful voices, O Son of God, Giver } \\
\text { of Life, for which the world glorifies Thee. }\end{array}$ \\
\hline
\end{tabular}

17 Коптілов В. В. Теорія і практика перекладу. Навчальний посібник / Віктор Вікторович Коптілов.- К. : Юніверс, 2003. - 280 с. - С. 9-10. 
Table 1 (continuance)

\begin{tabular}{|c|c|l|}
\hline & $\begin{array}{l}\text { Вечірня пісня Синові Божому } \\
\text { Світе тихий святия слави безсмертнаго Отца небесного, } \\
\text { святаго, блаженнаго, Ісусе Христе! Пришедше на запад } \\
\text { солнца, видівше світ вечерній, поєм Отца, Сина і Святаго } \\
\text { Духа, Бога. Достоїн єси во вся времена піт бити гласи } \\
\text { преподобними. Сине Божий, живот даяй: тім же мір Тя } \\
\text { славит } 18\end{array}$ \\
\hline 18.
\end{tabular}

${ }^{18}$ Вечірня пісня Синові Божому/Молитви богослужбові з вечірні. [Online]. Available: https://parafia.org.ua/biblioteka/molytvy/pravoslavnyj-molytoslov/molytvy-bohosluzhbovi-zvechirni.

${ }^{19}$ The Unabbreviated Horologion, Jordanville, New York: Holy Trinity Monastery (published 1997), 1992, pp. 192-193. 
Table 1 (continuance)

\begin{tabular}{|c|c|c|}
\hline$\dot{\sigma}$ & 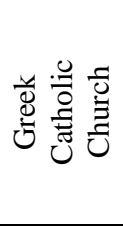 & $\begin{array}{l}\text { O Joyful Light of the holy glory of the Father Immortal, the } \\
\text { heavenly, holy, blessed One, O Jesus Christ, now that we have } \\
\text { reached the setting of the sun, and see the evening light, we sing } \\
\text { to God, Father, Son, and Holy Spirit (+). It is fitting at all times to } \\
\text { raise a song of praise in measured melody to you, O Son of God, } \\
\text { the Giver of Life. Therefore, the universe sings your glory. }{ }^{20} \text {. }\end{array}$ \\
\hline$\dot{\theta}$ & 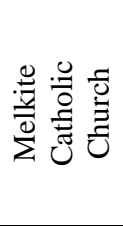 & $\begin{array}{l}\text { Oh, Joyful Light, of the Holy Glory of the Father Immortal. } \\
\text { Heavenly, Holy, Blessed, Jesus Christ, since we have come, to the } \\
\text { setting of the sun, and have seen the evening light, we praise God: } \\
\text { the Father, the Son, and the Holy Spirit (+). It is proper for you to } \\
\text { be praised at all times by fitting melody. Oh, Son of God, Giver of } \\
\text { Life, wherefore the world glorifies You. }\end{array}$ \\
\hline$\ddot{ت}$ & 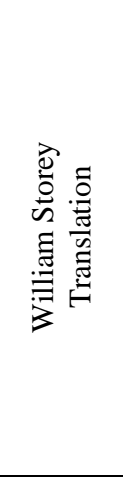 & $\begin{array}{l}\text { Used in the Office of the Dead and at Evening Prayer. } \\
\text { O radiant light, O sun divine } \\
\text { Of God the Father's deathless face, } \\
\text { O image of the light sublime } \\
\text { That fills the heav'nly dwelling place. } \\
\text { O Son of God, the source of life, } \\
\text { Praise is your due by night and day; } \\
\text { Our happy lips must raise the strain } \\
\text { Of your esteemed and splendid name. } \\
\text { Lord Jesus Christ, as daylight fades, } \\
\text { As shine the lights of eventide, } \\
\text { We praise the Father with the Son, } \\
\text { The Spirit blest and with them one. }\end{array}$ \\
\hline$\stackrel{\sim}{\approx}$ & 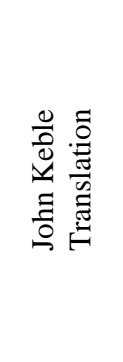 & $\begin{array}{l}\text { Hail, gladdening Light, of His pure glory poured } \\
\text { Who is the immortal Father, heavenly, blest, } \\
\text { Holiest of Holies, Jesus Christ our Lord! } \\
\text { Now we are come to the sun's hour of rest; } \\
\text { The lights of evening round us shine; } \\
\text { We hymn the Father, Son, and Holy Spirit divine! } \\
\text { Worthiest art Thou at all times to be sung } \\
\text { With undefiled tongue, } \\
\text { Son of our God, Giver of life, alone: } \\
\text { Therefore in all the world Thy glories, Lord, they own }{ }^{21} \text {. }\end{array}$ \\
\hline
\end{tabular}

20 "MCI - Publications of the Byzantine Catholic Church".[Online]. Available: metropolitancantorinstitute.org.

${ }^{21}$ Anglican Hymn Book \#54 /translated by John Keble// Church Book Room Press - 1965. [Online]. Available:. https://hymnary.org/text/hail_gladdening_light_of_his_pure_glory_ 
Table 1 (continuance)

\begin{tabular}{|c|c|c|}
\hline$\stackrel{\dot{m}}{\sim}$ & 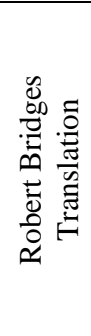 & $\begin{array}{l}\text { O gladsome light, O grace Of God the Father's face, } \\
\text { The eternal splendour wearing; Celestial, holy, blest, } \\
\text { Our Saviour Jesus Christ, Joyful in thine appearing. } \\
\text { Now, ere day fadeth quite, We see the evening light, } \\
\text { Our wonted hymn outpouring; Father of might unknown, } \\
\text { Thee, his incarnate Son, And Holy Spirit adoring. } \\
\text { To thee of right belongs All praise of holy songs, } \\
\text { O Son of God, Lifegiver; Thee, therefore, O Most High, } \\
\text { The world doth glorify, And shall exalt forever. }\end{array}$ \\
\hline$\dot{I}$ & 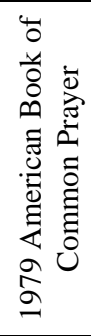 & $\begin{array}{l}\text { O gracious Light, } \\
\text { pure brightness of the everliving Father in heaven, } \\
\text { O Jesus Christ, holy and blessed! } \\
\text { Now as we come to the setting of the sun, } \\
\text { and our eyes behold the vesper light, } \\
\text { we sing your praises, O God: Father, Son, and Holy Spirit. } \\
\text { You are worthy at all times to be praised by happy voices, } \\
\text { O Son of God, O Giver of life, } \\
\text { and to be glorified through all the worlds. }\end{array}$ \\
\hline வ் & 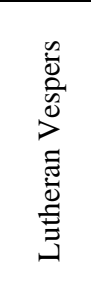 & $\begin{array}{l}\text { Joyous light of glory of the immortal Father, } \\
\text { Heavenly, holy, blessed Jesus Christ, } \\
\text { We have come to the setting of the Sun } \\
\text { And we look to the evening light. } \\
\text { We sing to God, the Father, Son and Holy Spirit. } \\
\text { You are worthy of being praised with pure voices forever. } \\
\text { O Son of God, O Giver of life, } \\
\text { The universe proclaims your glory. }\end{array}$ \\
\hline$\stackrel{\dot{\varphi}}{ }$ & 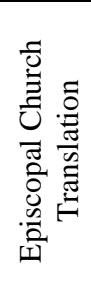 & $\begin{array}{l}\text { Light of the world in grace and beauty, } \\
\text { mirror of God's eternal face, } \\
\text { transparent flame of love's free duty, } \\
\text { you bring salvation to our race. } \\
\text { Now, as we see the lights of evening, } \\
\text { we raise our voice in hymns of praise; } \\
\text { worthy are you of endless blessing, } \\
\text { Sun of our night, Lamp of our days. }\end{array}$ \\
\hline
\end{tabular}

\section{CONCLUSIONS}

The theoretical basis of this study presents the conceptual scheme of D. Davidson, framenets and conceptual analysis based on Frame Semantics, deriving from the work of Charles J. Fillmore, the semantic scheme of Ch. Ogden and A. Richards, the dynamic / functional equivalence of E. Nida, classification of literary text information into three types by T. Nekryatch and Y.Chala, linguistic experience of componential analysis application (R. Jacobson, M. Kochergan, A. Kuznetsov, I. Kobozeva), 
R. Jackendoff's conceptual semantics models, conceptual equivalence as trnaslation quality assessment criterion.

The results of conceptual componential analysis on the example of the concept of "light" led to the following conclusions: 1) the Ancient Greek concept of "light" is represented in different religions and different Christian confessions demonstrating verbal continuity through religious and conceptual changeability, e.g., from polytheistic Slavonic paganism to nowadays' Christian confessions of Ukraine; 2) the verbalized concept of "light" sometimes knit together several religions into one text, e.g.,the

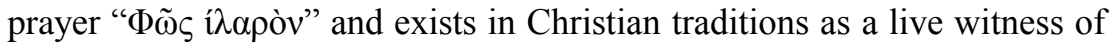
the former epochs; 3) the concept of "light" in a polytheistic religion is "reincarnated" in a monotheistic one, e.g., light of the sun is a giving life spirit of pagan god Dazhdboh (God of Sun) and the burning of the heaven fire of Svaroh).

Corpus-based conceptual seme analysis of verbalized religious concepts would facilitate the interrelations on the level of conceptual seme equivalence study. This idea found its realization in the mutual interdisciplinary project dedicated to the adaptable corpus development aimed at fulfillment of corpus-based componential concept analysis.

\section{SUMMARY}

This chapter studies a quality assessment criterion of specialist's translation based on translation analysis of the 4th century religious texts. A short historical outline of translatability issues in biblical and Christian literature translation led to the conclusion that religious translation has been facing mostly the same set of issues since that time till nowadays. The division of religious text information into three types underlines different nature of such texts themselves and proves that conceptual type of information is the frame on which other two types are based. Conceptual equivalence is used as an additional quality assessment criterion to evaluate already translated texts on the level of concept adequacy. Elements of componential and comparative analysis revealed some inadequacies in conceptual source and target language semes. The idea of corpus-based concept analysis with the help of parallel corpora or similar to FrameNet tools would facilitate the comparison of two or more texts on the level of their conceptual semes. 


\section{REFERENCES}

1. Вечірня пісня Синові Божому/Молитви богослужбові 3 вечірні. [Online]. Available: https://parafia.org.ua/biblioteka/molytvy/ pravoslavnyj-molytoslov/molytvy-bohosluzhbovi-z-vechirni.

2. Дэвидсон Д. Об идее концептуальной схемы / Д. Дэвидсон // Аналитическая философия. Избранные тексты [Сост. А.Ф. Грязнов]. М.: Изд-во МГУ. - 1986 - С. 144-159.

3. Иероним Стридонский. Письмо LVII. К Паммахию о наилучшем способе перевода / Иероним Стридонский; [пер. с латыни Н. Холмогоровой, под редакцией М. Касьян и Т. Миллер] // Альфа и Омега. № 4(7). - 1995. - С. 173-187.

4. Коптілов В. В. Теорія і практика перекладу. Навчальний посібник / Віктор Вікторович Коптілов. - К. : Юніверс, 2003. - 280 с. C. 4-58.

5. Некряч Т. Є. Через терни до зірок : труднощі перекладу художніх творів. Для студентів перекладацьких факультетів вищих навчальних закладів : навчальний посібник / Т. С. Некряч, Ю. П. Чала. Вінниця : Нова Книга, 2010. - 195 с.

6. Попович Н. М. Давньогрецька тринітарна термінологія у різномовних перекладах (На матеріалі патристичної літератури IV століття): монографія / науковий редактор проф. Клименко Н. Ф. Ужгород: Видавництво УжНУ «Говерла», 2018. - 309 с.

7. Lutskiv A., Popovych N. (8-11/10.2019). Adaptable Text Corpus Development for Specific Linguistic Research in Proc. of 2019 IEEE International Scientific and Practical Conference "Problems of Infocommunications. Science and Technology".

8. Kübler S. and Zinsmeister H., Corpus Linguistics and Linguistically Annotated Corpora (Englisch), New York; London: Bloomsbury Academic, 2015, P. 21-156. http://dx.doi.org/10.5040/9781472593573.

9. Naudé J., Religious translation / J. Naudé // Handbook of Translation Studies,ed. Yves Gambier and Luc van Doorslaer. Amsterdam / Philadelphia: John Benjamins Publishing Company. - Vol. 1. - 2010. - 458 p. P. 285-292.

10.Nida, Eugene A., Charles R. Taber. (1969). The Theory and Practice of Translation, With Special Reference to Bible Translating, 200. Leiden: Brill. - P. 1-55.

11. Nida E. A. Towards a science of translating. With special reference to principles and procedures involved in Bible translating / E. A. Nida. Leiden : Brill, 1964. - 331 p.

12. Ruppenhofer J., Ellsworth M., Petruck M. R. L, Johnson Ch. R., Baker Collin F., Scheffczyk Jan, FrameNet II: Extended Theory and 
Practice (Revised November 1, 2016.). [Online]. Available: https://framenet.icsi.berkeley.edu/fndrupal/the_book.

13. The Unabbreviated Horologion, Jordanville, New York: Holy Trinity Monastery (published 1997), 1992. P. 192-193.

\section{Information about the author:}

Popovych N. M.,

Doctor of Philosophy in Theory of Translation

(Candidate of Philological Sciences), Associate Professor at the Department of Multicultural Education and Translation of the State University "Uzhhorod National University"

14, Universytetska str., Uzhhorod, 88000, Ukraine 